\title{
HATE SPEECH LAW AND DISAGREEMENT
}

THE HARM IN HATE SPEECH. By Jeremy Waldron. ${ }^{1}$ Harvard University Press. 2012. Pp. vii + 292. \$26.95 (cloth).

\section{James Allan ${ }^{2}$}

Jeremy Waldron is erudite, well-published and well-known. He currently divides his time between being a professor of law at the New York University School of Law in the United States and being a Chichele Professor of Social and Political Theory at All Souls College, Oxford University in the United Kingdom, though the latter of these posts is comparatively recent. And of course prior to both of these Waldron held full-time positions at Columbia and Berkeley law schools and outside the law school world at Princeton University and Edinburgh University.

I mentioned above that Professor Waldron is well-published but putting it that way rather trivializes just how prolific and wide-ranging his writings have been. Waldron, a legal philosopher and philosopher more generally, has written on the idea of private property in relation to claims about fundamental rights; ${ }^{3}$ he has written on the Rule of Law; ${ }^{4}$ he has attempted to make a case for greater receptivity by United States courts to consider overseas case law $;^{5}$ he has delved into Kant's legal thinking; ${ }^{6}$ he has had an on-going interest in thinking about and

1. University Professor, New York University School of Law; Chichele Professor of Social and Political Theory, All Souls College, University of Oxford.

2. Garrick Professor of Law, University of Queensland, Australia; Card visiting Professor of Law, University Of San Diego School of Law. The author wishes to thank Larry Alexander, Richard Ekins, Adam Hirsch, Grant Huscroft and Steven Smith for their comments on an earlier draft. And thanks, too, to Christen Somerville.

3. JEREMY WALDRON, THE RIGHT TO PRIVATE PROPERTY (1988).

4. See, e.g., Jeremy Waldron, Is the Rule of Law an Essentially Contested Concept (in Florida)?, 21 L. \& PHIL. 137 (2002).

5. See Jeremy Waldron, Foreign Law and the Modern Ius Gentium, 119 HARV. L. REV. 129 (2005); but see my response and rejection of the Waldronian argument in James Allan, Jeremy Waldron and the Philosopher's Stone, 45 SAN DIEGO L. REV. 133 (2008) [hereinafter Allan, Philosopher's Stone].

6. See, e.g., Jeremy Waldron, Kant's Legal Positivism, 109 HARV. L. REV. 1535 
analyzing rights; ${ }^{7}$ and he has written on torture, ${ }^{8}$ to give just a sampling of the scope of Waldron's interests.

That said, it seems to me that Jeremy Waldron is best known ${ }^{9}$ for his work on strong judicial review of the American sort that empowers unelected top judges to gainsay the elected legislature, indeed to strike down and invalidate the statutes produced by these law-makers. Waldron is against giving this power to the judiciary ${ }^{10}$ though his opposition to this countermajoritarian practice appears latterly to have become more hedged about with qualifications, conditional premises and exceptions, ${ }^{11}$ or so it appears to me. ${ }^{12}$

Whether you agree with that "this is what Waldron is best known for" claim of mine, or not, remember it because it will make a cameo reappearance below. Indeed, it will form one ancillary plank of my argument that Waldron's underlying thesis in his most recent book is ultimately unpersuasive and unsatisfying.

I refer to Jeremy Waldron's The Harm in Hate Speech, a consideration of which will take up the rest of this review. In Part A I will briefly introduce the book, outline its contents and sketch Waldron's thesis and arguments. Then in Part B I will say why I think that Waldron fails in this book, by which I mean that he fails in the end to offer up a convincing, persuasive and satisfying argument for his ultimate position. Of course Waldron certainly does not fail in being interesting, erudite, informative and, at times, (my favorite) provocative.

(1996).

7. This starts as far back as Waldron's introduction to (and editorship of) THEORIES OF RIGHTS (Jeremy Waldron ed., 1984).

8. See, e.g., Jeremy Waldron, Torture and Positive Law: Jurisprudence for the White House, 105 COLUM. L. REV. 1681 (2005).

9. See Allan, Philosopher's Stone, supra note 5.

10. For a chronological sampling, see Jeremy Waldron, A Right-Based Critique of Constitutional Rights, 13 OXFORD J. LEGAL STUD. 18 (1993), Jeremy Waldron, Freeman's Defense of Judicial Review, 13 L. \& PHIL. 27 (1994), JEREMY WALDRON, LAW AND DisAGREEMENT (1999), and Jeremy Waldron, Eisgruber's House of Lords, 37 U.S.F. L. REV. 89 (2002).

11. See Jeremy Waldron, The Core of the Case Against Judicial Review, 115 YALE L.J. 1346 (2006).

12. Indeed I have alluded to this, and to how Waldron's normative case against giving judges over much moral input at the point-of-application does not seem to carry over into Waldron's preferred theory of constitutional interpretation-or to his view of statutory bills of rights. See Allan, Philosopher's Stone, supra note 5; See also James Allan, Fantastic Mr. Fox-A Review of Brian Simpson's "Reflections on 'The Concept of Law,'” 23 KING's L.J. 331, 337 (2012). 


\section{PART A - INTRODUCING THE BOOK AND ITS CONTENTS}

The Harm in Hate Speech was published in 2012. As Waldron himself makes clear in chapter one, the book's genesis lay in a review Waldron wrote for the New York Review of Books of a book by Anthony Lewis on the topic of free speech. ${ }^{3}$ It was the response to that review, at least in part, that Waldron tells us in his introductory first chapter that prompted him to flesh out that Lewis review into this book, The Harm in Hate Speech.

So in chapter two Waldron gives us an expanded version of that Lewis review of his. Then in chapters three and four we get Waldron's positive case, the most favorable account or defense of hate speech laws he can give. Chapter five deals largely with needed distinctions, complexities and qualifications, including the distinction crucial to his argument - the one distinguishing between offending people and attacking their dignity. Waldron, as you might suspect, does not think laws that regulate hate speech ought to extend to protecting against felt offense whereas they should, thinks Waldron, cover dignity-degrading or dignityenervating hateful words. And of course Waldron argues that he can uphold this distinction; that the latter (dignity protection) need not, even in the hurly burly of real-life regulation, regularly and consistently end up being used merely to prevent or foreclose speech that causes offense.

Chapters six and seven are defensive in nature. They can be thought of as pre-emptive replies or counter-arguments to the anti-hate speech laws positions firstly of C. Edwin Baker (chapter six) and secondly of Ronald Dworkin (chapter seven). The last chapter of the book, chapter eight, then turns to history. Here Waldron attempts to draw a link between the modern debate over hate speech laws and the Enlightenment concern with religious toleration, Waldron arguing that the two are, or at least can be understood to be, connected.

If that is a bare outline of the structure of the book, let me now turn to the gist of Waldron's argument in The Harm in Hate Speech.

First off, I need to make it abundantly clear that Waldron does not offer up an argument about American First

13. ANTHONy Lewis, Freedom for the Thought That We Hate: A BIOGRAPHY OF THE FIRST AMENDMENT (2007). 
Amendment jurisprudence: "Still less is it my aim to make a case for the constitutional acceptability of [hate speech] laws in the United States" (p.11, but see also p. 103, inter alia), he says. Of course there are occasional asides about how the existing U.S. case law may, just, leave scope for some sort of constitutionally valid hate speech laws (see p.28 ff, inter alia). But more than once Waldron concedes that "... it is unlikely that [anti-hate speech] legislation... will ever pass constitutional muster in America" (p.11).

So it is not that sort of parsing-of-precedents book, nor even a "here's what a return to first principles constitutional interpretation of the sort I advocate could achieve" one. No, Waldron eschews all that. This book, instead, aims to "come to terms with the best that can be said for hate speech regulations" (p.11). It aims to make a plausible or maybe even persuasive case in favor of hate speech laws. This will involve offering the most defensible characterization of these laws that Waldron can.

And at core what Waldron does is to offer what amounts to a consequentialist argument to that effect. When you throw everything into the balance, the real harm that vilifying and humiliating vulnerable groups does will, on occasion, outweigh the costs that come from using the law to silence people, even in some instances when the hateful words are not inciting or provoking violence. That is the gist of the Waldronian case.

Along the way, of course, Waldron needs to tell us what for him falls under the aegis of "hate speech." And in different ways and in different places in the book he does. It is publications (because Waldron is far more concerned with the written word that is lasting rather than the spoken word that is ephemeral) "which express profound disrespect, hatred, and vilification for members of minority groups" (p. 27); it is a species of "group defamation" or "group libel" claim (see pp. 39-41, inter alia); it is "assaults upon the dignity of the persons affected" (p. 59); "[i]t is a matter of status - one's status as a member of society in good standing" (p. 60); and so the point is "that hate speech laws really are enacted for the benefit of vulnerable racial, ethnic, and religious minorities, to uphold their reputation and their dignity" (p. 203).

As you can see from those few selected passages, the concept of "dignity" plays a large role in Waldron's argument. Hence Waldron spends no small amount of time explaining that "dignity is a complex idea" (p. 59), but at its core it refers to 
people's "basic social standing, the basis of their recognition as social equals and as bearers of human rights and constitutional entitlements" (p. 59).

The real, tangible harm of hate speech, says Waldron, is its "radical denigration of status and [its] undermining of [the] assurance [of decent treatment and respect]" (p. 108). And so the legislating against hate speech can also be understood in terms of "public order" (p. 53) benefits or the goal of "a wellordered society" (pp.77-78). And in making the best case he can for some regulation or outlawing of hate speech Waldron has various other quivers in his bow. He makes an analogy to arguments seeking laws against pornography ( $p$ p. 89-92, inter alia); he puts weight on practices in other democratic countries (pp. 13, 40, 57-58, 149, inter alia); as mentioned already, he distinguishes undermining dignity from causing offense (much of chapter five); and he takes on, preemptively, two well-known thinkers who dislike speech regulation (chapters six and seven).

As I hope I have made clear already, The Harm in Hate Speech offers a nuanced and erudite case for us to think again about the desirability of hate speech laws. That said, Waldron's argument ultimately fails, in my opinion; it is unpersuasive and unconvincing, on the grounds I now set out.

\section{PART B - WHY WALDRON'S ARGUMENT FAILS}

As Waldron starts his book with a sort of confessional account of why he came to write this book, let me also lay my cards on the table. You see, unlike many readers, I am broadly in the Waldron camp in disliking bills of rights and strong judicial review, on democratic grounds. ${ }^{14}$ So the critique that follows of Waldron's "best case for hate speech laws" will take

14. See, e.g., James Allan, Bills of Rights and Judicial Power-A Liberal's Quandary 16 OXFORD J.LEGAL STUD. 337 (1996); see also JAMES ALLAN, SYMPATHY AND ANTIPATHY: Essays Legal AND PhILOSOPHICAL (2002); James Allan, Rights, Paternalism, Constitutions and Judges, in Litigating Rights: PeRsPeCtives FROM DOMESTIC AND INTERNATIONAL LAW 29 (Grant Huscroft \& Paul Rishworth eds., 2002); James Allan, Oh That I Were Made Judge in the Land, 30 FED. L. REV. 561 (2002); James Allan, A Modest Proposal, 23 OXFord J. LEgAL STUD. 197 (2003); James Allan, An Unashamed Majoritarian, 27 DALHousiE L.J. 537 (2004); James Allan \& Grant Huscroft, Rights Internationalism Coming Home to Roost? 43 SAN DIEGO L. REV. 1 (2006); James Allan, Portia, Bassanio or Dick the Butcher? Constraining Judges in the Twenty-First Century, 17 KINGS's L.J. 1 (2006); James Allan, Thin Beats Fat Yet AgainConceptions of Democracy, 25 L. \& PHIL. 533 (2006); Allan, Philosopher's Stone, supra note 5; James Allan, Meagher's Mischaracterisations of Majoritarianism, 20 KING'S L.J. 115 (2009); JAMES Allan, THE VANTAGE OF LAW: ITS ROLE IN THINKING ABOUT LAW, JUDGING AND BILLS OF RIGHTS (2011). 
place on Waldron's home turf, as it were. It will not be a "the judges should have done $\mathrm{X}, \mathrm{Y}$ or $\mathrm{Z}$ " type critique that points to some supposed lack of understanding of the First Amendment case law. Instead, I want to point out weaknesses in the Waldronian argument taken on its own terms. And I turn to do that now, under the following five headings.

\section{1) WHAT REALLY IS THE UNDERLYING NATURE OF WALDRON'S ARGUMENT?}

I said above that Waldron offers a consequentialist argument that tries to make the best case it can in favor of hate speech laws. And I was careful to put it in those terms because here and there Waldron says such things as "my aim is not directly to advocate hate speech laws in the United States" (p. 103 , and see p. 11). On the other hand, there are times when Waldron does, in fact, seem to be arguing in favor of hate speech laws. When talking of vulnerable minorities and the hurt hateful speech can cause them he says that "[w]e don't have to dissect any of this and present it in a pure form in order to understand the wrongness of hate speech and the wisdom of legislating against $i t$ " (p. 114, emphasis added). Or when telling us how he is using the concept of dignity, Waldron says that he "used it in the course of making an argument about the desirability of certain legislation" (p. 138).

So, in fact, it is not at all clear in this book whether Waldron's aim is actually to support the enactment of some variety or other of hate speech laws, even in the United States, or whether it is something much woolier and more in the nature of a Harvard Law School seminar discussion, with Waldron pointing out that much more can be said on the other side of the argument than most others suppose, or maybe just plain out playing Devil's advocate.

Readers will have to decide for themselves which it is Waldron really wishes to do. For my part, I would have preferred the book had it been the case that Waldron had just stated plainly that he was arguing in favor of a limited variety of hate speech laws. And I would have preferred that not because my guess is that that is in fact Waldron's position (though that is my guess) or that the equivocation is slightly grating (though it is), but rather because it would have forced Waldron to be more specific as to just what he wanted. And that might have either bolstered his case, or shown up a few weaknesses. 
For instance, at no point in the entire book does Waldron give us a draft hate speech law that he would endorse. You don't really need to do that when you're making the Harvard Law School seminar best-case-you-can for such laws. You can point to various bits of overseas legislation (as Waldron regularly does), and when pushed say that these "are something for legislators to consider" (p. 173, also pp. 176-77).

But if you are in fact arguing for some sort of limited hate speech laws - arguing that these are a good idea-then it seems to me that you need to tell us what they will look like, or at least sketch an outline. Merely pointing overseas, as I shall argue below, has problems of its own, including the dangers of cherrypicking, and of failing to distinguish between criminal and noncriminal hate speech law regimes.

I also said above that Waldron's argument is in essence a consequentialist one. Yes, at times in discussing the concept of dignity the argument briefly moves to more Kantian footings. But that is not Waldron's ultimate aim in this book. Here he wants dignity to be understood in more down-to-earth terms and he most definitely wants the reader to see, and to acknowledge, that hateful, vilifying speech has clear bad consequences.

And surely Waldron is correct about that. And yet as consequentialist arguments go there is undoubtedly more to be thrown in the balance than the many harms of hateful speech that Waldron notes. I am not here referring to Dworkin's claim that the bad consequences claims made by hate speech laws' proponents are inflated (pp. 176, 183). Take them to be every bit as bad as Waldron suggests. Nevertheless, that is surely not the end of any robust consequentialist weighing up of costs and benefits. We might also like to consider such other things as how over-inclusive such hate speech laws might prove to be (see below); what the knock-on effects will be on a judiciary asked to decide if speech has "humiliated or terrorized" (p. 84) individuals in particular groups; what the costs of putting in jail those not cowed by these laws might be (see below as regards Canada); and I would have thought we might also like some sort of comparative analysis of where the vulnerable groups Waldron focuses upon, say Muslims, do better or worse today-right now-in terms of being included-in-society, members-in-goodstanding, dignity-bearing citizens. Is it in the U.S. without hate speech laws or is it in the U.K. or Germany or France or the countries with hate speech laws that Waldron repeatedly refers to? 
You see it is far from clear to me that the answer to that question is not already the U.S., the lack of hate speech laws notwithstanding. And if that is correct, or even almost correct (barring a Scandinavian country or two), then that might also affect one's consequentialist calculation of the need for hate speech laws - if much of what you want them for is already better achieved here than in places that have them, and we recognize that such laws will carry bad consequences, as well as potential dignity-enhancing ones.

Instead Waldron merely makes rather brief mention of the potential dangers of these hate speech laws in terms of their possibly fostering identity politics (p. 131), or their undermining the need in society for a certain degree of having a thick skin ( $\mathrm{p}$. 126).

But for me, at least, it was an unsatisfying sort of consequentialist case that Waldron makes in favor of hate speech laws-assuming, of course, that he is wanting to make that case and not just seeking to raise our awareness that more can be said on the other side of this debate.

\section{2) Just Precisely How Do Hate Speech LAws BoOst DIGNITY?}

At its very core, Waldron's argument is that properly designed and limited hate speech laws can boost the dignity of vulnerable minority groups by stopping or reducing attempts to undermine the assurance society makes to them that they have the status of being members "in good standing."

But a very big question is just how do hate speech laws do that? How do they boost dignity? Or put the other way round, how does hate speech itself undermine this assurance?

And as far as I could tell, Waldron never really makes it clear how exactly he thinks hate speech undermines this assurance of good standing and how laws against such speech themselves undermine that undermining. ${ }^{15}$

There are three things Waldron could have said in reply. One possible reply would be that hate speech attacks dignity and undermines the assurance of good standing in society by conveying information to its target groups. This speech that is

15. The next two points I make are in part the fruit of an interesting conversation I had on this with Larry Alexander. 
hostile to and contemptuous of them gives them information about the feelings and views and attitudes of the speakers.

On this first mooted Waldronian reply, what hate speech laws do to boost dignity is to suppress this information. The target groups then do not get to find out what the hate speakers think of them. And this delivers to such target groups a certain sense of security, but it is not a reliable sense of security. It might even be a false sense of security. And that is because the hate speech laws do not change or lessen the attitudes and beliefs of the people cowed by these laws into silence; rather these laws simply keep the target groups from learning about the existence of these attitudes.

There are very few hints of this sort of answer to the 'how do hate speech laws boost dignity?' question in The Harm in Hate Speech. ${ }^{16}$ And that is surely because such a "willful blindness is better than knowing the truth" rationale for supporting hate speech laws is so weak and unpersuasive.

A second possible reply by Waldron-one that is much more likely that he had in mind-is that hate speech undermines the assurance of good standing by its effects on listeners outside the target group. It persuades some of them. It changes their opinions. The hate multiplies.

And that fear is surely a possibility and one whose likelihood and bad effects need to be thrown into the consequentialist hopper or ledger when assessing the desirability of hate speech laws. Indeed Waldron alludes to this second possible reply in terms of hate speech being a signaling to others tool and a focal point for proliferation (see, inter alia, pp. 94-95). So by stamping out or reducing hate speech by the sanctions attached to law you prevent the proliferation and so boost-or, perhaps more accurately, do not further diminish-dignity.

Yet there are real problems with this second mooted reply as to how precisely it is that hate speech undermines the assurance to vulnerable groups of their being members of society in good standing. One very obvious difficulty with this second mooted basis for claiming that hate speech laws can boost dignity of some people in vulnerable groups is that it requires you to take a very dim and pessimistic view as to the capabilities

16. But see p. 95 ("It is sometimes objected that such laws simply drive hate speech underground. But in a way, that is the whole point ...."). 
and capacities of your fellow citizens. Indeed Waldron concedes that this is precisely the case (p. 153).

Now it may well be that many people, not least in the Harvard Law School faculty lounge, think such pessimism is more than warranted when it comes to "the first 200 names in the Boston phone book." ${ }^{17}$ I do not share that pessimistic view. But many might and some of them may be prepared to argue for the truth of such pessimism. And to the extent they were convincing, then to that same extent would this second mooted reply gain in plausibility.

Of course whatever your view on the underlying merits of the pessimist's case as regards the foibles and weaknesses of one's fellow citizens and their inabilities to see through the rantings of Nazis (pp. 94, 95, 226), of cross-burners and KKK members (pp. 77, 81, 94, 102, 113), of Holocaust deriders (p. 102) and of those peddling homophobic abuse (pp. $116 \mathrm{ff}$ ), it seems that Waldron himself is in a particularly difficult position in running this line. After all, the Waldron of days gone by (and recall that I agree with that early Waldron) argued against overpowerful judges and opposed strong judicial review precisely on the basis that much disagreement in society, including disagreements about fundamental and hotly contested issues understood in terms of rights, were best seen as reasonable disagreements. ${ }^{18}$ Put more bluntly, the early Waldron is nothing if not optimistic about the capacities of his fellow citizens.

Now, I will return below to this question about whether the core arguments in this book are easily made by a Jeremy Waldron who wishes to remain consistent with his earlier positions and views, but for now just note the potential difficulty for Waldron (as opposed to others with a long-standing pessimism about the capabilities of regular voters and citizens). And consider, too, whether it helps Waldron to lay the blame for this distrust (p. 153) at the feet of real-life legislators who opt to enact these hate speech laws. There might be scope for the "best-case-I-can-make" Waldron to finesse the issue in those terms. But a Waldron who wanted, in fact, to argue for the enactment of hate speech laws would need to tell us what he thinks about the capacities of his fellow citizens and whether he

17. See William F. Buckley, JR., Quotations from Chairman Bill: The BEST OF WILLIAM F. BUCKLEY, JR. 117-18 (1970) (quoting WiLliAM F. BUCKLEY, JR., Rumbles Left AND Right: A Book About Troublesome People and IdeAs 134 $35(1963))$.

18. See supra, note 10. 
thinks we ought to be pessimistic or optimistic on that score of the ability of Joe Average Citizen to withstand and see through the rantings of Holocaust denying neo-Nazis. (And if it be the latter, that Waldron is himself optimistic about his fellow citizens' capacities, then for Waldron this second mooted reply loses most of its force).

On top of that, there are problems with this second mooted reply that apply to anyone offering it up as a ground for thinking that hate speech undermines the assurance of good standing and that hate speech laws can fix that to some extent (and so boost dignity).

Here the main difficulty with the "fear of these ideas proliferating" defense of hate speech laws is that it works so much better if you simply assume all such speech is false. What if you worry, though, that some small percentage of it is true? Or that you can't be sure where to draw the line foreclosing false and true speech? In other words, what if you have real worries about how this will all play out in the real world and that any hate speech regime-any set of laws Waldron himself can articulate-will end up being over-inclusive (and no doubt under-inclusive too)?

It seems to me that these are very deep and concerning waters indeed, this issue of what speech will be ruled out for its hateful and dignity-diminishing nature that may in fact turn out to be true speech or end up indirectly pushing others to see the truth. Worse, it also strikes me that Waldron fudges or finesses this issue in the book.

For instance, Waldron includes under the aegis of hate speech those publications not just directed at race but those directed also at religion. Indeed on the very first page of the book he gives what the reader must assume is an example of hateful speech that the law ought to suppress by raising the hypothetical of a Muslim man out walking with his two young children who sees a sign saying "Muslims and 9/11! Don't serve them, don't speak to them, and don't let them in" (p. 1). Yet this particular example of dignity-diminishing words directed at religion never really raises the truth issue (of a religion's tenets, that is, not of its causal link to terrorism). So what if the sign had instead simply quoted Professor Richard Dawkins and read that Islam is "one of the great evils of the world"? ${ }^{19}$ Surely that is as

19. Dale Miller, "There's no God and Islam is evil" speech earns Richard Dawkins ovation from islanders, THE SCOTSMAN, (Mar. 3, 2012), http://www.scotsman.com/the- 
likely to affect the dignity of the children in the hypothetical, and of the father too. And all the more so coming from a worldfamous atheist.

Would Waldron seek to outlaw that? I suspect not. But Waldron's attempts to explain which talk about other religions is okay, and which not, never really make clear how you distinguish these two. Indeed, for me, there is a tad too much of what Waldron himself in other contexts terms "happy talk" about how we all ought to be sensitive to others' religious beliefs and such things. But of course many people are not. And what you are advocating with hate speech laws, at the end of the day, is attempting to silence people through threats, big fines and yes, putting them in jail. (See below as regards to Canada.)

So anyone offering up this second mooted reply about how hate speech can dangerously persuade others needs to tell us more than Waldron does about how and when we can be sure that speech about, say, religion is clearly false. Or failing that, he or she would need to come out of the closet and assert that no religion or religious tenets can ever lawfully be disparaged (which, to be clear, is not Waldron's position, it is just that things may move that way in practice if Waldron cannot specify what his position is). ${ }^{20}$ Accordingly, I do not find this second possible reply to the question of how hate speech laws will boost dignity all that much more persuasive than the first one.

That leaves a third and final possible reply as to how this might come about, how hate speech laws can reduce attempts to undermine the assurance to people in vulnerable groups of their being in good standing in society. And here we turn from how hate speech can persuade others (the focus of the second mooted reply) to how its outlawing and criminalization might affect the speaker. Maybe such laws will, after all, change the vile views and attitudes of some of these speakers?

Certainly Waldron himself never relies on this possibility. Indeed he is abundantly clear that it is not his aim, through hate speech laws, to change anyone's beliefs. The issue does get an airing in the book's final chapter, but this is clearly a very weak basis on which to rest any justification for hate speech laws, and

scotsman/scotland/there-s-no-god-and-islam-is-evil-speech-earns-richard-dawkinsovation-from-islanders-1-2612951.

20. And linked to this criticism is the one I make below about Waldron's overseas cherry-picking and focusing only on criminal law hate speech provisions (as in Canada with the Keegstra case) rather than on the vastly more used civil law sanctions, where truth is not a defense. 
Waldron rests nothing on it. So I merely mention it as a possibility here because it might be that you could combine aspects of this third mooted possibility with bits of the above second one to hint at an argument in terms of politeness and socialization being how hate speech laws might achieve the bolstering of dignity.

This combined sort of possibility might go like this: Lots of people, and maybe everyone, will have nasty or mean-spirited tendencies, and socialization involves teaching people to overcome and control these, instilling in us a sense of what "is done" and what "just isn't done"-of what is "normal" in the sense of both usual and normative. So if we know that something "isn't done," we may still have desires to do it, but we come to think that we should try to control these desires. Likewise (sort of, maybe), if a hateful thing is said, the very saying of it tends to normalize it, and if the thing is said under permission, the normalization is stronger. So just as with parents teaching children the basic etiquette of politeness, hate speech laws effect a type of socialization process of what is and is not acceptable speech, and even attitudes. So maybe that sort of hybrid of possibilities two and three process is how we are to think that hate speech laws will boost dignity?

Alas, even this last wholly speculative hybrid possibility of mine $^{21}$ seems implausible. At core it is an argument about changing speakers' views and beliefs and still strikes me as a poor candidate even when spiced up with bits of the second possibility.

So as far as trying to understand just how hate speech laws might boost dignity and how hate speech itself might undermine Waldron's goal of assuring all and sundry that they have the status of being members of society "in good standing"-the quite hard to pin down how this might all work claims - these were the only three and a half possibilities I could come up with. And none, alone or together, is overly persuasive.

\section{3) IS WALDRON CHERRY-PICKING?}

Part of Jeremy Waldron's argument in this book, quite a large part in fact, involves pointing to all sorts of other democratic jurisdictions, noting that they have hate speech laws,

21. In an earlier form it was first mooted by Steven Smith in a discussion I had with him. 
and asking you to consider if - at least in this instanceAmerican exceptionalism is a good idea or a better than even bet. So Waldron makes repeated references to the United Kingdom and its Public Order Act, and to Canada and the top court's decision there in $R$. v Keegstra, ${ }^{22}$ and to Australia, and to his native New Zealand, and more.

But if we take two of those jurisdictions that I know passingly well, then it seems to me that Waldron leaves himself open to the charge that he has cherry-picked his examples. Start with Canada. Waldron refers to the Keegstra case, a more than two decades old Supreme Court of Canada decision, in four separate parts of the book. And it certainly is an important and leading decision that upheld the constitutionality of criminal hate speech laws in Canada against attack on the Charter of Rights' freedom of expression grounds.

Yet in Canada, or so it seems to me, the criminal law plays a small to insignificant role in the government's attempt to suppress hate speech. Most of the action, nay the vast preponderance of the action, takes place in administrative tribunals where truth is not even a defense, where complainants have all of their costs picked up by the taxpayer but the accused do not, and where penalties include five-figure fines and (I mean this seriously) tribunal-backed-by-the-court orders never to speak on certain matters again. ${ }^{23}$

It was in this non-criminal law realm that political commentator Mark Steyn was ensnared when the biggest selling Canadian news weekly magazine (largely considered to be mildly on the left-of-center of Canadian politics, if that matters to you) published an article that was an excerpt of a chapter of Steyn's New York Times Number One best seller, America Alone. And in that article (and chapter, and book), Steyn pointed to unchallenged demographic trends related to high birthrates for Muslims but not for others and expressed grave concerns about their political, social and cultural implications.

Steyn and that news magazine McLeans were accused of hate speech and dragged before three separate jurisdictions' tribunals, the Ontario Human Rights Commission, the British Columbia Human Rights Commission and the Canadian Human Rights Commission, by a serial complainant, an official of the

22. [1990] 3 S.C.R. 697 (Can.).

23. See Lund v. Boissoin, 2008 AHRC 6 (Can.), rev'd, Lund v. Boissoin, 2012 ABCA 300 (Can.). 
Canadian Islamic Council. In some of these tribunals no accused had ever prevailed - not a single person ever-in the entire time of these tribunals' existence. Complainants had a 100 percent success track record. Those accused of hate speech always lost.

Now the cases against McLeans were eventually dropped, not least because McLeans had deep pockets and the cases were embarrassing all sorts of people, but not before the defendants had spent in excess of $\$ 2$ million on that defense. ${ }^{24}$

Or one could point to the Saskatchewan Christian evangelist, Bill Whatcott, who was taken before a Saskatchewan equivalent tribunal and fined for his publications condemning "sodomite" sex. The man strikes me as a quack, but I very much doubt he diminishes anyone's dignity. At any rate, Whatcott appealed all the way to the Supreme Court of Canada, which earlier this year decided unanimously against him and upheld the constitutionality of these civil hate speech laws, laws that do not even make truth a defense-indeed the Supreme Court of Canada in Whatcott explicitly said that "truth may be used for widely disparate ends." " Whatcott vows now to continue speaking, which means he will be imprisoned for contempt of court, in theory until his will is broken, or for life.

And there are dozens and dozens and dozens of similar cases from Canada-hundreds if you count the many people who are accused of hate speech, and who would like to fight but who opt on prudential grounds to make a perfunctory apology, pay a fine and get away.

So just to be clear, the criminal law route for limiting hate speech in Canada - with its various built-in safeguards related to the burden of proof, to truth being a defense and to prosecutions needing the consent of the Attorney-General-has at a high level only one single successfully prosecuted case that I know of

24. This was told to me, in person, by Mark Steyn. I have no supplementary proof of this claim.

25. Saskatchewan (Human Rights Commission) v. Whatcott, 2013 SCC 11, para. 137 (Can.). Of course it is also true that the Supreme Court of Canada read down the non-criminal hate speech law, severing concepts including dignity: "However, expression that 'ridicules, belittles or otherwise affronts the dignity of' does not rise to the level of ardent and extreme feelings constituting hatred required to uphold the constitutionality of a prohibition of expression in human rights legislation." Id. at 18. And the Court also narrowed what "hatred" means, further than prior precedents, by saying it was an objective reasonable-person standard. In short, the Supreme Court of Canada "upheld" the constitutionality of a different law, with one possible implication being that the Court doesn't want it used too much. 
this past quarter century. That's Keegstra, the one Waldron repeatedly refers to in this book.

Meantime speech-restricting laws that get a near daily workout in Canada-laws where truth is not a defense, complainants get their costs paid but not the accused, just being offended comes close sometimes to seeming to be enough, and more-receive not a single mention from Waldron in this entire book when he looks beyond American shores to weigh up the costs and benefits of hate speech laws.

Of course, it is also the case that on my reading of this book, given that Waldron never directly addresses the point, I would conclude that Waldron is probably against this whole Canadianstyle administrative law "hate speech tribunal" machinery that focuses in part on mere subjective offence and that does not make truth a defense. But I would like to have heard Waldron say so, to tell us whether truth ought to be a defense and all the rest, and to do so in no uncertain terms.

And as a big believer, like me, in legislative sovereignty, Waldron might also have mentioned that Canada's federal parliament is on the verge of repealing the federal non-criminal s.13 Human Rights Commission hate speech laws. ${ }^{26}$ Readers might even wonder whether the solely criminal law hate speech reducing Keegstra ${ }^{27}$ machinery, on its own, could ever accomplish anything like the volume of speech suppression that would be needed to make any difference at all to the sort of dignityenhancement that Waldron cares about-the sort of speechsuppressing work done in Canada not by the criminal law but by these tribunals with all sorts of characteristics of which I infer Waldron disapproves.

Or turn to Australia. The main vehicle for attempting to suppress hate speech there is likewise not the criminal law. And as it happens the current Opposition political party in their federal Parliament has pledged to repeal this non-criminal hate speech law, ${ }^{28}$ so the battle in Australia (where there is no

26. Canadian Human Rights Act, R.S.C., 1985, c. H-6, s. 13 (Can.); See Charlie Gillis, Section 13: How the battle for free speech was won, MACLEAN's (June 19, 2012), http://www2.macleans.ca/tag/bill-c-304. The Bill to repeal it has been passed through the elected lower house, and on June 27th was passed through the wholly unelected and appointed Upper House Senate. Royal Assent is just a formality and once given the provision will be repealed.

27. R. v. Keegstra, [1990] 3 S.C.R. 697 (Can.).

28. See Malcolm Farnsworth, Tony Abbott Speech on Free Speech, Australian POLITICS.COM, (Aug. 6, 2012), http://australianpolitics.com/2012/08/06/tony-abbottspeech-on-free-speech.html (Federal Opposition leader Tony Abbott addressed the 
national bill of rights of any sort) is taking place wholly on Waldron's and my preferred turf. But even if we focus on the courts in Australia, and on this non-criminal law machinery, we see that the big, notorious case involving hate speech laws there is the Eatock $v$ Bolt case. ${ }^{29}$ That case involved a right-of-center (phew!) political pundit who commented that self-identifying Aborigines with mere traces of Aboriginal blood were scooping up too many affirmative action rewards. It is a case anyone familiar with the Elizabeth Warren saga in the U.S. would immediately recognize..$^{30}$

And the political commentator, Bolt, lost. He had to pay a small fine, make a pseudo-apology, remove the newspaper column in question from all websites, and avoid speaking on the same matter again. Based on the legislation the judge ruled that Bolt could have made his criticisms less stridently. A key pillar of the judge's reasoning was that he didn't like Bolt's tone!

Again, I assume that Waldron would not endorse any of this. But then neither does he mention any of it. And as I noted above, in any full-blooded consequentialist weighing up of the pros and cons of the sort of limited, targeted, not applying to mere offense, leaving truth as a defense, Waldronian-style hate speech laws, we will surely want to consider whether these are the sort of contained and bracketed laws that we will end up with down the road. Or whether they will transmogrify into what you see in the non-criminal law realm in Canada today.

\section{4) IS THE HATE SPEECH WALDRON CONSISTENT WITH THE "NO STRONG JUDICIAL REVIEW" WALDRON?}

I can be brief here. My comments are directed at the issue of how easy it is for Jeremy Waldron in particular (as opposed to someone without his skepticism of strong judicial rule) to write this book. I pointed out above that there is a certain sort of pessimism about the capacities of one's fellow citizens to see through hate-mongers that runs through what is probably the most plausible (but still weak) account of just how it is that hate speech might undermine the assurance of good standing and so possibly require the enactment of hate speech laws. And I

Institute of Public Affairs about the importance of free speech and repealing Section 18(c) of the Racial Discrimination Act).

29. Eatock v Bolt (No. 2) [2011] FCA 1180 (Austl.).

30. Garance Franke-Ruta, Is Elizabeth Warren Native American or What?, THE ATLANTIC (May 20, 2012), http://www.theatlantic.com/politics/archive/2012/05/iselizabeth-warren-native-american-or-what/257415. 
[Vol. 29:59

queried whether Waldron could actually come out and openly say that he himself was pessimistic about his fellow citizens' abilities. Or rather whether he could do that today without undermining some of his earlier core positions that buttressed his arguments against strong judicial review.

Frankly, I am somewhat doubtful on that score, but I also recognize that someone of Waldron's erudition and abilities may have reconciling arguments that I have yet to anticipate. So I just raise those doubts.

However, related to this theme of whether Waldron has changed any of his earlier views, there is another passage in this book that seems to me to call for further clarification. Waldron claims that:

I belong to a school of thought that accepts that the tasks assigned to courts and administrators in matters of fundamental rights (rights to free expression, rights to dignity) will often be delicate and challenging, often involve balancing different goods, and essaying difficult value judgments [with a citation to his July 2011 British Academy Review paper "Thoughtfulness and the Rule of Law" and to Ronald Dworkin's Freedom's Law: The Moral Reading of the Constitution] (pp. 115-16).

To which I am inclined to ask, 'Really?' The Waldron of the articles cited in note 10, above, and of Moral Truth and Judicial Review $^{31}$ and of Ego-Bloated Hovel ${ }^{32}$ and of Some Models of Dialogue between Judges and Legislators, ${ }^{33}$ and more again, accepts that there ought to be a lot of moral input at the pointof-application of laws? Certainly on my understanding of what it means to be a normative legal positivist or democratic legal positivist (into which category I put myself and into which category I thought that Waldron put himself) the desire is to limit or minimize judges' scope for moral and normative input at the point-of-application-be it for good consequentialist reasons (my thinking) or because you build up from non-consequentialist equality grounds to a "right to participate in social decisionmaking," making this your "right of rights" (which is more or less what I took Waldron to think).

31. 43 AM. J. JURIS. 75 (1998).

32. 94 Nw. U.L. REV. 597 (2000).

33. See Jeremy Waldron, Some Models of Dialogue Between Judges and Legislators, in CONSTITUTIONALISM IN THE CHARTER ERA (Grant Huscroft \& Ian Brodie eds., 2004). 
Of course a very careful reading of the above passage from the book could read the term "accepts" near the start to be an "is" claim rather than an endorsing "ought" claim, in which case Waldron might just be acknowledging the state of play in a world with constitutionally entrenched bills of rights as in Canada or the U.S.. Yet that is not the most obvious reading of that passage, especially given that it is made in the context of disavowing hate speech laws that would be "presented with rulelike clarity, uncontroversially administrable, requiring nothing ${ }^{34}$ in the way of further moral judgment or careful thought and discretion" (p. 115).

And then there are the various hints throughout this book that the core goal of hate speech laws is not so much to block and suppress any particular set of ideas, however loathsome, but more to stop particularly nasty and crude articulations of those ideas. Yet this "just rephrase what you want to say in less epithet-laden terms and you can still say it" position seems to me to be quite precariously close to one that amounts to legislating in favor of intelligent people, Harvard Law School type people, who have the resources to frame their beliefs (however nasty) in terms that will pass some sort of "how did you say what you believe?" test. In other words, it works against the common man and woman. And we can even speculate on whether such a Waldron-mandated need to say things the proper way might not have the unintended and undesired effect of making certain detestable views more persuasive and more effective than they would otherwise be, by putting a clever and moderate-sounding new spokeswoman on an old National Front soap box, as it were. Who knows?

What I think I can say, though, is that parts of the argument in The Harm in Hate Speech left me wondering whether Waldron had changed or refined or qualified any of the views related to his well-known anti-strong judicial review position.

34. Of course as Waldron himself has made clear in the past, no one really argues for no moral or normative input at the point-of-application, as that would be impossible. The argument is a relative one, to keep this to a bare minimum so as to increase the input of voters and legislators. See Jeremy Waldron, Normative (or Ethical) Positivism, in HART'S POSTSCRIPT: ESSAYS ON THE POSTSCRIPT TO THE CONCEPT OF LAW 411-33 (Jules L. Coleman ed., 2001). 
5) IS WALDRON'S ATTEMPT TO DISTINGUISH "CAUSING OFFENCE" AND "UNDERMINING DIGNITY" CONVINCING?

I can be even briefer here. Despite Waldron's erudite attempts to distinguish speech that merely causes offence (and so ought not to be silenced by law) and speech that undermines the dignity of the listener (which, at least potentially, ought to be silenced) I remained doubtful about the ability of any real-life hate speech law to implement this distinction. That is not just because Waldron at times in this book talks of the need for laws to protect against "being discriminated against or humiliated" (p. 84, inter alia) and that I cannot ultimately see how being humiliated is any less of a subjective issue (so not about one's objective standing in society with only ancillary effects as regards one's feelings) than being offended. To my mind, if dignityundermining differs from offence-giving then it seems to me it must also differ from causing humiliation.

Nor is it just because Waldron in this book tells us he is "not a supporter of the proposal to ban the burqa [for liberty and freedom of religion reasons while, oddly, suggesting that a main reason for wanting the ban is the desire not to be seen by the world as a society of religious conservatives]" (p. 76), and I found myself thinking that that stance of his might be hard to square with his desire to have the law uphold a sort of objective test of being a "non-degraded member of society in good standing." 35

It is also because I believe that drafting any statutory provision that is to be enacted in the hope of criminalizing some set of words that will undermine dignity but at the same time that will never directly or just criminalize the hurting of the feelings of others is beyond the wit of man. Which may or may not be why Waldron never offers the reader any suggested draft laws that show this skepticism of mine is misplaced. But I leave this issue wholly for the reader to decide.

\section{CONCLUSION}

I want to repeat that this is a thought-provoking, stimulating, and erudite book. At the same time I think that it ultimately fails to convince if you come to the book as I do,

35. Which may be why Waldron admits the burqa ban issue is "complicated" (p. 76), and concedes that "the arguments that are used to support a burqa ban are not a million miles from the arguments that I am pursuing in this book" (p. 77). I would have put the distance somewhat closer than Waldron does. 
someone happy to consider the various costs and benefits of enacting hate speech laws (however limited). In addition, the book would have benefitted if Waldron had seen fit to include even a couple of examples of hate speech emanating from people other than the usual suspects of neo-Nazis, skinheads, Islamaphobes, KKK members, cross-burners and Holocaust deniers that he trots out. Surely there are some examples of antiSemitic hate speech from Black Muslim leaders, say, that might have been included, or from Imams in the United Kingdom, or perhaps some vile speech more generally from some of today's rap music or examples directed at Mormons. Anything to dispel the patently false lurking suggestion that dignity-diminishing speech comes only (or overwhelmingly) from the extremes of one side of politics.

Of course in a fundamental sense I agree whole-heartedly with that manifestation of Waldron that argues here and there in this book that it should be left to elected legislators whether to enact hate speech laws. Indeed I prefer, too, that these laws also be removed by those same legislators, as has now partially taken place in Canada and possibly will do so in Australia after their next election. It is just that I disagree with Waldron that the case for having such laws is at all convincing or persuasive. And I say that despite Waldron's efforts in this book to change the minds of people like me.

Whatever the harm in hate speech, my view is that any set of real life hate speech laws that Waldron might have proposed had he seen fit to do so would either have had vanishingly few dignity-enhancing effects in practice or it would have rather massively over-reached, as in Canada. The costs would outweigh the benefits. 